Case Report

\title{
Aeromonas sobria Induced Sepsis Complicated with Necrotizing Fasciitis in a Child with Acute Lymphoblastic Leukemia
}

\author{
Manuela Colosimo ${ }^{1}$, Maria Concetta Galati ${ }^{2} \oplus$, Umberto Riccelli ${ }^{3}$, Simona Paola Tiburzi ${ }^{4}$, Eulalia Galea ${ }^{2}$, \\ Teresa Alcaro ${ }^{1}$, Orazio Stefano Giovanni Filippelli ${ }^{4}$, Francesco Abbonante ${ }^{3}$, Pasquale Minchella ${ }^{1}$ \\ and Luca Gallelli $5,6, *$ (D) \\ check for \\ updates \\ 1 Operative Unit of Microbiology and Virology, "Pugliese Ciaccio" Hospital, 88100 Catanzaro, Italy; \\ manuelacolosimo@hotmail.it (M.C.); teresaalcaro86@gmail.com (T.A.); minchellap@tin.it (P.M.) \\ 2 Department of Oncology and Hematology, "Pugliese Ciaccio" Hospital, 88100 Catanzaro, Italy; \\ mcgalati@aocz.it (M.C.G.); eulgal@yahoo.it (E.G.) \\ 3 Operative Unit of Plastic Surgery, Department of Surgery, "Pugliese Ciaccio" Hospital, 88100 Catanzaro, Italy; \\ umbertoriccelli@hotmail.it (U.R.); franco.abbonante@gmail.com (F.A.) \\ 4 Department of Critical Care and Intensive Unit, "Pugliese Ciaccio" Hospital, 88100 Catanzaro, Italy; \\ tiburzi1@virgilio.it (S.P.T.); oraziofilippelli@alice.it (O.S.G.F.) \\ 5 Clinical Pharmacology Unit "Mater Domini” Hospital, Department of Health Science, \\ University Magna Graecia of Catanzaro, 88100 Catanzaro, Italy \\ 6 Research Center FAS@UMG, Department of Health Science, University Magna Graecia of Catanzaro, \\ 88100 Catanzaro, Italy \\ * Correspondence: gallelli@unicz.it; Tel.: +39-096-171-2322
}

Citation: Colosimo, M.; Galati, M.C.; Riccelli, U.; Tiburzi, S.P.; Galea, E.;

Alcaro, T.; Filippelli, O.S.G.;

Abbonante, F.; Minchella, P.; Gallelli,

L. Aeromonas sobria Induced Sepsis

Complicated with Necrotizing

Fasciitis in a Child with Acute

Lymphoblastic Leukemia. Reports

2021, 4, 9. https://doi.org/10.3390/

reports 4020009

Academic Editor: Toshio Hattori

Received: 26 January 2021

Accepted: 24 March 2021

Published: 26 March 2021

Publisher's Note: MDPI stays neutral with regard to jurisdictional claims in published maps and institutional affiliations.

Copyright: (c) 2021 by the authors. Licensee MDPI, Basel, Switzerland. This article is an open access article distributed under the terms and conditions of the Creative Commons Attribution (CC BY) license (https:// creativecommons.org/licenses/by/ $4.0 /)$.

\begin{abstract}
Aeromonas species are gram negative and able to induce systemic diseases (i.e., gastrointestinal, respiratory, and cardiovascular, diseases, in addition to infection of brain and soft tissues). In this study, we describe the development of necrotizing fasciitis in a young immunocompromised girl, with a low response to drug treatment and who died after some months.
\end{abstract}

Keywords: Aeromonas infection; young child; immunocompromised girl

\section{Introduction}

Aeromonas species are gram negative, non-sporulating facultative anaerobic bacilli that produce $\beta$-lactamases [1], able to colonize both humans and animals [2]. Aeromonas is ubiquitous in water, including chlorinated drinking water, where flagella facilitate biofilm formation [3]. The virulence of Aeromonas is multifactorial, due to cytotoxic, cytolytic, hemolytic, and enterotoxin proteins $[4,5]$. In human infections, the most common clinical isolates are Aeromonas hydrophila, Aeromonas caviae, and Aeromonas veronii biovar sobria [6], that induce systemic diseases (i.e., gastrointestinal, respiratory, and cardiovascular diseases, in addition to infection of brain and soft tissues) [7-9]. Aeromonas infections can develop in healthy and trauma patients, but immunocompromised hosts with hematological malignancies or solid tumors are considered to be at greatest risk [10].

In this study, we describe the development of necrotizing fasciitis in a young immunocompromised girl.

\section{Case Presentation Section}

We report a 6-year-old Caucasian girl with acute lymphoid leukemia that developed a necrotizing fasciitis related to Aeromonas veronii biovar sobria infection.

On 28 July, 2019 the patient was admitted to the Operative Unit of pediatric haematooncology with a diagnosis of acute lymphoid leukemia (EGIL B-II subtype) to start the standard chemotherapy protocol (Table 1). 
Table 1. Chemotherapy protocol used for acute lymphoid leukemia (EGIL B-II subtype). AEIOP ALL (Associazione Italiana di Ematologia e Oncologia Pediatrica-acute lymphoid leukemia) 2017.

\begin{tabular}{|c|c|c|c|}
\hline Date (2019) & Phase & Cycle & Drugs \\
\hline 16 January & Induction & & edoxaban plus 6-mercaptopurine \\
\hline 18 February & & First & \multirow{2}{*}{ cytosine arabinoside } \\
\hline 1 April & & Last & \\
\hline 18 April & Consolidation & & 6-mercaptopurine \\
\hline 25 April & & First & \multirow{2}{*}{ Methotrexate } \\
\hline 11 June & & Last & \\
\hline 8 July & Induction & & Dexamethasone \\
\hline 15 July & & First & \multirow{2}{*}{ Vincristine + Adriamycin + pegaspargase } \\
\hline 22 July & & Last & \\
\hline
\end{tabular}

The patient was hospitalized for clinical evaluation and laboratory findings revealed a severe decrease in blood cells (red cells $3.37 \times 10^{3} / \mathrm{mcl}$, normal range 4.2-6.1; white cells $1.17 \times 10^{3} / \mathrm{mcl}$, normal range 4.6-10.20; hemoglobin $10.5 \mathrm{gr} / \mathrm{dL}, 12-18$; platelets $119 \times 10^{3} / \mathrm{mcl}$, normal range $130-400$; prothrombin time $68 \%$, normal range $80-120$ ) and an increase in liver enzymes (GPT ALT $97 \mathrm{IU} / \mathrm{L}$, normal range 0-41; azotemia $54 \mathrm{~g} / \mathrm{dL}$, normal range 10-50) (see Table 2). Therefore, on 29 July, dexamethasone ( $2 \mathrm{mg} /$ day orally) was added. On 30 July, the patients developed fever $\left(39^{\circ} \mathrm{C}\right)$ with bilateral ankle and knee fleeting erythema that disappeared within $1 \mathrm{~h}$. Biochemical analysis revealed an increase in liver enzymes (GPT $139 \mathrm{IU} / \mathrm{L}$; GOT $56 \mathrm{IU} / \mathrm{L}$ normal range 0-38), and a severe decrease in blood cell counts (red cells $2.1 \times 10^{3} / \mathrm{mcl}$; white cells $0.6 \times 10^{3} / \mathrm{mcl}$; platelets $50.2 \times 10^{3} / \mathrm{mcl}$ ).

Therefore, platelets were transfused, acetaminophen $(10 \mathrm{~mL} /$ day os) was administered, and a blood sample was taken for microbiological evaluation.

On 31 July, the patient referred to severe pain in the right upper limb (visual analogue scale, VAS, 8) with an increase in body temperature $\left(37.7^{\circ} \mathrm{C}\right)$, that worsened 1 day later (01 August) (fever $39^{\circ} \mathrm{C}$; VAS 10). Therefore, treatment with acetaminophen $(10 \mathrm{~mL} /$ day os) and tramadol (8 gtt) was started, without clinical benefit. Clinical parameters were in the normal range (blood pressure, $\mathrm{BP}, 90 / 50 \mathrm{mmHg}$; $\mathrm{SPO} 297 \%$; heart frequency 160 beats $/ \mathrm{min}$ ); echo-color doppler and chest X-rays excluded phlebitis, deep venous thrombosis, or pulmonary diseases. Laboratory findings confirmed the decrease in blood cell counts (red cells $3.37 \times 10^{3} / \mathrm{mcl}$; white cells $0.47 \times 10^{3} / \mathrm{mcl}$; platelets $\left.23.9 \times 10^{3} / \mathrm{mcl}\right)$.

On 02 August, a new clinical evaluation revealed the presence of fever $\left(38.6{ }^{\circ} \mathrm{C}\right)$ and severe pain (VAS 10), edema, and skin rash of the right upper limb. Laboratory testing revealed a decrease in liver function and plasma proteins, and an increase in procalcitonin levels (Table 2). Microbiology diagnosed a sepsis caused by Aeromonas veronii biovar resistant to ampicillin (minimal inhibitory concentration $(\mathrm{MIC})>32$ ), but sensitive to ciprofloxacin (MIC $<0.06$ ), ceftriaxone (MIC $<0.25$ ), cefuroxime (MIC $<1$ ), trimethoprim/sulphametoxazole (MIC < 20), and ceftazidime (MIC < 0.12). An antimicrobial, antiviral, and antimycotic empirical treatment plus acetaminophen $(10 \mathrm{~mL}$ os) and ketorolac (10 mg i.m.) was started without clinical benefit. 
Table 2. Time course of biochemical parameters. GOT: glutamic oxaloacetic transaminase; gamma-GT: gamma-glutamyl transpeptidase; INR: international normalized ratio; LDH: lactate dehydrogenase.

\begin{tabular}{|c|c|c|c|c|c|c|c|c|c|c|c|c|c|}
\hline & July & & & & & & & & & & & Normal Range & Unit \\
\hline Parameters & 28 & 2 & 3 & 8 & 11 & 13 & 16 & 20 & 25 & 27 & 28 & & \\
\hline Red blood cells & 3.37 & 2.73 & 2.83 & 3.44 & 3.63 & 3.37 & 2.81 & 2.35 & 2.9 & 2.8 & 5.4 & $4.6-10.20$ & $10^{3} / \mu \mathrm{L}$ \\
\hline White blood cells & 1.17 & 0.04 & 0.07 & 1.51 & 7.61 & 6.53 & 6.19 & 3.65 & 4.75 & 5.4 & 2.79 & $4.2-6.1$ & $10^{6} / \mu \mathrm{L}$ \\
\hline Platelets & 119 & 8.67 & 20 & 62 & 38 & 39 & 25 & 12 & 11 & 43 & 43 & $130-400$ & $10^{3} / \mu \mathrm{L}$ \\
\hline Hemoglobin & 10.5 & 8.2 & 8.5 & 9 & 10.9 & 10.3 & 8.8 & 7.1 & 8.7 & 8.2 & 8.2 & $012-018$ & $\mathrm{gr} / \mathrm{dL}$ \\
\hline Creatinine & 0.4 & 0.2 & 0.4 & 1.3 & 0.7 & 1.1 & 0.8 & 0.7 & 0.5 & 0.7 & 0.7 & $0.5-1.2$ & $\mathrm{mg} / \mathrm{dL}$ \\
\hline GOT & 36 & 111 & 166 & 9 & 15 & 14 & 22 & 17 & 16 & 16 & 24 & $0-38$ & $\mathrm{IU} / \mathrm{L}$ \\
\hline Gamma-GT & 30 & 58 & 97 & 110 & 126 & 120 & 90 & 85 & 70 & 50 & 50 & 005-36 & $\mathrm{IU} / \mathrm{L}$ \\
\hline $\mathrm{LDH}$ & 220 & 267 & 327 & 157 & 220 & 389 & 463 & 495 & 442 & 640 & 726 & $135-250$ & IU/L \\
\hline Azotemia & 54 & 20 & 30 & 35 & 40 & 83 & 105 & 122 & 171 & 170 & 166 & 010-50 & $\mathrm{gr} / \mathrm{dL}$ \\
\hline Total Bilirubin & 0.32 & 0.7 & 3.01 & 1.64 & 1.2 & 1.08 & 0.88 & 0.75 & 0.8 & 0.9 & 0.8 & $0-1.2$ & $\mathrm{mg} / \mathrm{dL}$ \\
\hline Albumin & 3.5 & 2.2 & 2.6 & 3.1 & 3.2 & 3.5 & 4.1 & 3.5 & 4.3 & 4.3 & 4.3 & $3.5-5.5$ & $\mathrm{gr} / \mathrm{dL}$ \\
\hline Total protein & 4.1 & 4.4 & 4.6 & 5 & 5 & 5 & 5.2 & 5.6 & 6.9 & 7 & 7 & $6-8.7$ & $\mathrm{gr} / \mathrm{dL}$ \\
\hline INR & 1.12 & 1.23 & 1.24 & 1.46 & 1.72 & 1.29 & 1.25 & 1.46 & 1.24 & 1.3 & 1.32 & $0.80-1.20$ & \\
\hline Prothrombine Time & 68 & 54.3 & 58.6 & 42.9 & 37.2 & 50.7 & 52.9 & 42.8 & 42.5 & 49 & 49 & $80-120$ & $\%$ \\
\hline Firinogen & 72 & 403 & 560 & 266 & 338 & 317 & 293 & 347 & 226 & 198 & 249 & $200-450$ & $\mathrm{mg} / \mathrm{dL}$ \\
\hline Procalcitonin & & 46.2 & 44.35 & 24.7 & 21.18 & 8.7 & 7.79 & 7.5 & 7.3 & 7.2 & 8 & $<0.05$ & $\mathrm{ng} / \mathrm{mL}$ \\
\hline
\end{tabular}

On 03 August, a clinical impairment was observed, and a swab of the skin rash was sent for a new microbiology evaluation. Abdominal ultrasound was normal, whereas the echo-color Doppler of the right upper limb showed a diffuse edema of skin soft tissues without signs of thrombosis with normal function of the venous tract. Blood chemical testing confirmed the low levels of red cells with a decrease in liver function (Table 2). Blood gas analysis documented a severe respiratory failure (PO2 $33 \mathrm{mmHg}$; PCO2 $32 \mathrm{mmHg}$ ) therefore the patient was transferred to the intensive care unit (ICU).

In the ICU, the right upper limb appeared marbled with edema and severe pain (VAS 10). Dexamethasone was discontinued and a treatment with furosemide, piperacillin + tazobactam, acyclovir, clindamycin, and oxygen was started.

On 04 August, clinical evaluation documented that the patient was in comatose status and an infection sustained by Klebsiella species was detected (Table 3). On 06 August, the fasciotomy of the right limb revealed the presence of a black fluid where microbiology testing detected the presence of Aeromonas veronii biovar sobria (resistant to ampicillin, MIC $>32$, but sensitive to ceftazidime MIC $<0.12$, cefuroxime MIC $<1$, ceftriaxone MIC < 0.25 , and ciprofloxacin MIC < 0.06). On physical examination, her lower limb was warm in the presence of erythema. After $12 \mathrm{~h}$, the swelling of her leg and the progression of skin lesions (circumferential erythema developed in bullae formations) increased until the development of a compartment syndrome, which rapidly required a surgical treatment with fasciotomy and negative pressure wound therapy (Figure 1). 


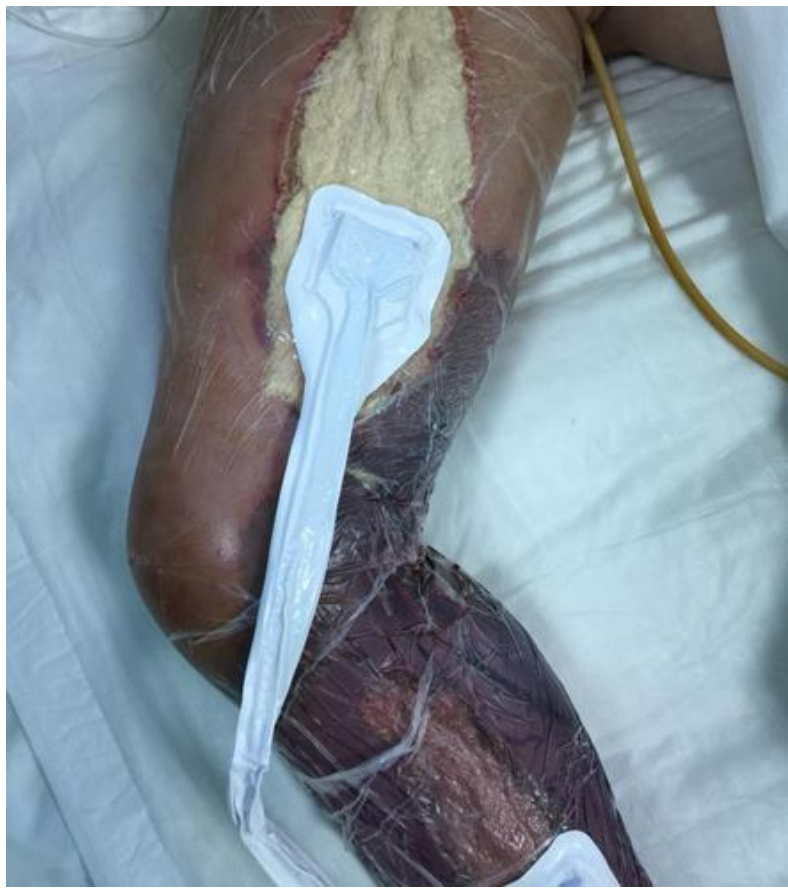

Figure 1. Surgical treatment with fasciotomy in young child.

Table 3. Klebsiella species isolated from swab surgical wound of the right lower limb on 04 August 2019. S: sensitive; R: resistant.

\begin{tabular}{ccc}
\hline Drugs & MIC $(\mu \mathrm{g} / \mathrm{mL})$ & Effect \\
\hline Amikacin & $<1$ & $\mathrm{~S}$ \\
Ampicillin & $>32$ & $\mathrm{R}$ \\
Amoxicillin/Clavulanate & $>32$ & $\mathrm{R}$ \\
Cefepime & $<0.12$ & $\mathrm{~S}$ \\
Cefotaxime & $<0.25$ & $\mathrm{~S}$ \\
Ceftazidime & $<0.25$ & $\mathrm{~S}$ \\
Cefuroxime & $<1$ & $\mathrm{~S}$ \\
Ciprofloxacin & $<0.06$ & $\mathrm{~S}$ \\
Ertapenem & 0.5 & $\mathrm{~S}$ \\
Fosfomycin & $<0.16$ & $\mathrm{~S}$ \\
Gentamycin & $<1$ & $\mathrm{~S}$ \\
Levofloxacin & $<0.12$ & $\mathrm{~S}$ \\
Piperacillin/tazobactam & $<4$ & $\mathrm{~S}$ \\
\hline
\end{tabular}

On 19 August, microbiological evaluation of surgical amputation of the distal lower limb (Figure 2) documented a positivity for Enterococcus faecium multi-resistant (ampicillin MIC > 32; Amoxicillin/clavulanate MIC > 32; streptomycin MIC SYN-R; Teicoplanin MIC > 32; Vancomycin MIC > 32; Linezolid MIC 2; Tigecycline MIC < 0.12). 


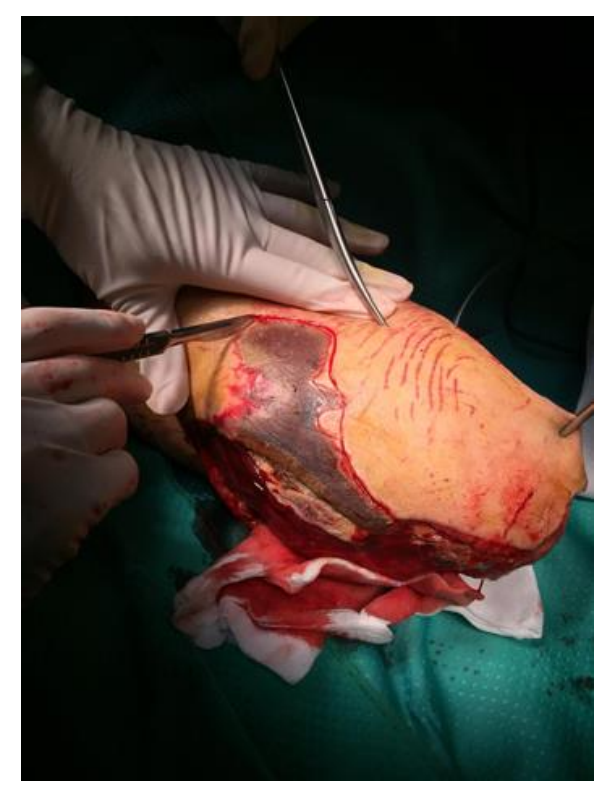

Figure 2. Surgical treatment with limb amputation.

On 22 August, microbiological evaluation of urine sample documented an infection sustained by the Acinetobacter Bahmani complex (Table 4$)$; therefore, tigecycline $(30 \mathrm{mg} / 12 \mathrm{~h})$ was added to the therapy, but after 7 days, due to both the progression of leukemia and the presence of a severe antimicrobial resistance infection (Table 4), the child died.

Table 4. Acinetobacter Bahmani complex infection in urine sample on 22 August 2019. S: sensitive; R: resistant.

\begin{tabular}{ccc}
\hline Drugs & MIC $(\mu \mathrm{g} / \mathrm{mL})$ & Effect \\
\hline Amikacin & $>16$ & $\mathrm{R}$ \\
Ampicillin & $>8$ & $\mathrm{R}$ \\
Aztreonam & $>4$ & $\mathrm{R}$ \\
Cefazoline & $>16$ & $\mathrm{R}$ \\
Cefepime & 8 & $\mathrm{R}$ \\
Cefixime & $>1$ & $\mathrm{R}$ \\
Cefotaxime & $>32$ & $\mathrm{R}$ \\
Cefoxitin & $>16$ & $\mathrm{R}$ \\
Ceftazidime & $>32$ & $\mathrm{R}$ \\
Cefuroxime & $>8$ & $\mathrm{R}$ \\
Ciprofloxacin & $>1$ & $\mathrm{R}$ \\
Ertapenem & $>1$ & $\mathrm{R}$ \\
Fosfomycin & 64 & $\mathrm{R}$ \\
Gentamycin & $>4$ & $\mathrm{R}$ \\
Imipenem & $>8$ & $\mathrm{R}$ \\
R Levofloxacin & $\mathrm{R}>1$ & $\mathrm{R}$ \\
Mecilliname & $>8$ & $\mathrm{R}$ \\
Meropenem & $>32$ & $\mathrm{R}$ \\
Norfloxacin & $>1$ & $\mathrm{R}$ \\
Piperacillin & $>16$ & $\mathrm{R}$ \\
Ticarcillin & $>16$ & $\mathrm{R}$ \\
Tobramycin & $>4$ & $\mathrm{R}$ \\
Trimethoprim & $>4 / 16$ & $\mathrm{R}$ \\
Trimethoprim /sulphametoxazole & $>4$ & $\mathrm{R}$ \\
\hline
\end{tabular}

\section{Discussion}

In this paper, we report an uncommon case of Aeromonas sobria sepsis with necrotizing fasciitis in an immunocompromised child. In a previous manuscript, Zhang et al. [11] evalu- 
ated 15 patients globally (median age 49.5 years; range: $27-80$ years) and documented that, in patients with acute myeloid leukemia or acute lymphoblastic leukemia and Aeromonas sobria infection, the most common manifestation was the lower limb infection $(66.7 \%)$. In this study, the authors reported that even if an empirical antibiotic treatment is started, the mortality is high. In our case presentation, we describe the development of sepsis and lower limb infection in a young child (6 years) with acute lymphoblastic leukemia. The patient developed a first-time sepsis and then lower limb infection despite starting empirical antimicrobial treatment. This effect could be related to the co-administration of corticosteroid and chemotherapy. To date, no definitive data have been published regarding the correlation between glucocorticoid treatment and systemic infection. However, Fardet et al. [12], based on analysis of a primary care database, documented that glucocorticoid use can induce the development of respiratory infections, even if they were not able to evaluate the role of chemotherapy or biological drugs in these infections. In our study, chemotherapy probably increased the risk of septicemia by Aeromonas sobria with the development of lower limb infection. Radiological chest and ultrasound excluded the presence of other systemic diseases, and swabs excluded the presence of infection in other sites and, after a few days, fasciculitis induced a systemic impairment with severe respiratory failure and immune depression. Systemic antimicrobial therapy did not reduce the infection. Both fasciotomy and amputation of the lower limb improved the symptoms, but after a few days, the clinical condition worsened. Microbiology detected a multi-resistant Aeromonas in tissues and, despite antimicrobial treatment being started, the patient died.

\section{Conclusions}

In conclusion, this study suggests that the risk of lower limb infection in the presence of Aeromonas infection must be carefully evaluated, in order to quickly start an appropriate antimicrobial treatment.

Author Contributions: Conceptualization, M.C. and U.R.; methodology, M.C.G., T.A., E.G.; investigation, M.C., S.P.T., O.S.G.F.; resources, F.A., P.M.; data curation, M.C., E.G., S.P.T.; writing-original draft preparation, M.C.; writing—review and editing, L.G.; supervision, F.A., P.M., L.G. All authors have read and agreed to the published version of the manuscript

Funding: This research received no external funding.

Institutional Review Board Statement: The study was conducted according to the guidelines and the study was approved by the local institutional review board.

Informed Consent Statement: Written informed consent has been obtained from the parents of the child.

Conflicts of Interest: The authors declare no conflict of interest.

\section{References}

1. Janda, J.M.; Abbott, S.L. Evolving concept regarding the genus Aeromonas: An expanding Panorama of species, disease presentation, and unanswered questions. Clin. Infect. Dis. 1998, 27, 332-344. [CrossRef] [PubMed]

2. Ghenghesh, K.S.; Ahmed, S.F.; El-Khalek, R.; Al-Gendy, A.; Klena, J. Aeromonas-associated infections in developing countries. J. Infect. Dev. Ctries. 2008, 2, 81-98. [CrossRef] [PubMed]

3. Fiorentini, C.; Barbieri, E.; Falzano, L.; Matarrese, P.; Baffone, W.; Pianetti, A.; Katouli, M.; Kühn, I.; Möllby, R.; Bruscolini, F.; et al. Occurrence, diversity and pathogenicity of mesophilic Aeromonas in estuarine waters of the Italian coast of the Adriatic Sea. J. Appl. Microbiol. 1998, 85, 501-511. [CrossRef] [PubMed]

4. Costerton, J.W.; Stewart, P.S.; Greenberg, E.P. Bacterial biofilms: A common cause of persistent infections. Science 1999, 284, 1318-1322. [CrossRef] [PubMed]

5. Rahim, Z.; Khan, S.I.; Chopra, A.K. Biological characterization of Aeromonas spp. isolated from the environment. Epidemiol. Infect. 2004, 132, 627-636. [CrossRef] [PubMed]

6. Janda, J.M.; Reitano, M.; Bottone, E.J. Biotyping of Aeromonas isolates as a correlate to delineating a species-associated disease spectrum. J. Clin. Microbiol. 1984, 19, 44-47. [CrossRef] [PubMed]

7. Daily, O.P.; Joseph, S.W.; Coolbaugh, J.C.; Walker, R.I.; Merrel, B.R.; Rollins, D.M.; Seidler, R.J.; Colwell, R.R.; Lissner, C.R. Association of Aeromonas sobria with human infection. J. Clin. Microbiol. 1981, 13, 769-777. [CrossRef] [PubMed]

8. Ko, W.C.; Chuang, Y.C. Aeromonas bacteremia: Review of 59 episodes. Clin. Infect. Dis. 1995, 20, 1298-1304. [CrossRef] [PubMed] 
9. Chang, H.; Hung, Y.S.; Shie, S.S.; Lin, T.L. Fulminant necritizingfascitis caused by Aeromonas sobria in neutropenic patients. Intern. Med. 2012, 51, 3287-3290. [CrossRef] [PubMed]

10. Tsai, M.S.; Kuo, C.Y.; Wang, M.C.; Wu, H.C.; Chien, C.C.; Liu, J.W. Clinical features and risk factor for mortality in Aeromonas bacteremic adults with hematologic malignancies. J. Microbiol. Immunol. Infect. 2006, 39, 150-154. [PubMed]

11. Zhang, L.; Li, J.; Zhou, D.-B.; Zhu, T.-N. Aeromonas sobria Infection in Patients with Acute Leukemia: Clinical Features and Outcome. Zhongguo Yi Xue Ke Xue Yuan Xue Bao 2015, 37, 711-714. [PubMed]

12. Fardet, L.; Petersen, I.; Nazareth, I. Common Infections in Patients Prescribed Systemic Glucocorticoids in Primary Care: A Population-Based Cohort Study. PLoS Med. 2016, 13, e1002024. [CrossRef] [PubMed] 